\title{
Ice nucleating particles in the marine boundary layer in the Canadian Arctic during summer 2014
}

Victoria E. Irish ${ }^{1}$, Sarah J. Hanna ${ }^{1}$, Megan D. Willis ${ }^{2}$, Swarup China ${ }^{3}$, Jennie L. Thomas ${ }^{4,5}$, Jeremy J. B. Wentzell ${ }^{6}$, Ana Cirisan ${ }^{7}$, Meng Si ${ }^{1}$, W. Richard Leaitch ${ }^{8}$, Jennifer G. Murphy ${ }^{2}$, Jonathan P. D. Abbatt ${ }^{2}$, Alexander Laskin ${ }^{9}$, Eric Girard $^{7, \dagger}$, and Allan K. Bertram ${ }^{1}$

${ }^{1}$ Department of Chemistry, University of British Columbia, 2036 Main Mall, Vancouver BC, V6T 1Z1, Canada

${ }^{2}$ Department of Chemistry, University of Toronto, 80 St George Street, Toronto, Ontario, ON M5S 3H6, Canada

${ }^{3}$ Environmental Molecular Sciences Laboratory, Pacific Northwest National Laboratory, Richland, WA 99354, USA

${ }^{4}$ Université Grenoble Alpes, CNRS, IRD, Grenoble-INP, IGE, 38000 Grenoble, France

${ }^{5}$ Laboratoire Atmosphères, Milieux et Observations Spatiales, Université Pierre et Marie Curie, 4 place Jussieu, 75252 Paris CEDEX 05, France

${ }^{6}$ Air Quality Research Division, Environment and Climate Change Canada, 4905 Dufferin Street, Toronto, ON M3H 5T4, Canada

${ }^{7}$ Département des sciences de la Terre et de l'atmosphère, Université du Québec à Montréal, 201, avenue du

Président-Kennedy, Montréal, Québec, QC H2X 3Y7, Canada

${ }^{8}$ Climate Research Division, Environment and Climate Change Canada, 4905 Dufferin Street, Toronto ON, M3H 5T4, Canada

${ }^{9}$ Department of Chemistry, Purdue University, West Lafayette, IN 47907, USA

$\dagger$ deceased

Correspondence: Allan K. Bertram (bertram@chem.ubc.ca)

Received: 17 July 2018 - Discussion started: 5 September 2018

Revised: 20 December 2018 - Accepted: 4 January 2019 - Published: 25 January 2019

\begin{abstract}
Ice nucleating particles (INPs) in the Arctic can influence climate and precipitation in the region; yet our understanding of the concentrations and sources of INPs in this region remain uncertain. In the following, we (1) measured concentrations of INPs in the immersion mode in the Canadian Arctic marine boundary layer during summer 2014 on board the CCGS Amundsen, (2) determined ratios of surface areas of mineral dust aerosol to sea spray aerosol, and (3) investigated the source region of the INPs using particle dispersion modelling. Average concentrations of INPs at -15 , -20 , and $-25^{\circ} \mathrm{C}$ were $0.005,0.044$, and $0.154 \mathrm{~L}^{-1}$, respectively. These concentrations fall within the range of INP concentrations measured in other marine environments. For the samples investigated the ratio of mineral dust surface area to sea spray surface area ranged from 0.03 to 0.09 . Based on these ratios and the ice active surface site densities of mineral dust and sea spray aerosol determined in previous laboratory studies, our results suggest that mineral dust is a more important contributor to the INP population than sea spray aerosol
\end{abstract}

for the samples analysed. Based on particle dispersion modelling, the highest concentrations of INPs were often associated with lower-latitude source regions such as the Hudson Bay area, eastern Greenland, or north-western continental Canada. On the other hand, the lowest concentrations were often associated with regions further north of the sampling sites and over Baffin Bay. A weak correlation was observed between INP concentrations and the time the air mass spent over bare land, and a weak negative correlation was observed between INP concentrations and the time the air mass spent over ice and open water. These combined results suggest that mineral dust from local sources is an important contributor to the INP population in the Canadian Arctic marine boundary layer during summer 2014. 


\section{Introduction}

Ice nucleating particles (INPs) initiate the heterogeneous formation of ice in clouds at temperatures warmer than required for homogeneous freezing. INPs are important since they can change the frequency and properties of ice and mixed-phase clouds. The frequency and properties of clouds in the Arctic have been shown to be especially sensitive to concentrations of INPs, yet our understanding of the concentrations and sources of INPs in this region remains uncertain (Coluzza et al., 2017; Creamean et al., 2018; Harrington et al., 1999; Kanji et al., 2017; Korolev et al., 2017).

Examples of atmospherically relevant INPs include, but are not limited to, mineral dust particles and sea spray aerosol (DeMott et al., 2016; Després et al., 2012; Hoose and Möhler, 2012; Murray et al., 2012; Niemand et al., 2012; Szyrmer and Zawadzki, 1997). Sea spray aerosol is generated by a bubble bursting mechanism at the ocean surface (Blanchard, 1964) and varies widely in composition, depending on the mechanism of formation. For example, particles from film rupture are enriched in organics compared to particles from jet droplets (Wang et al., 2017). Recent work has shown that the sea surface microlayer and bulk seawater contain INPs (Irish et al., 2017; Rosinski et al., 1986; Schnell, 1977; Schnell and Vali, 1975, 1976; Wilson et al., 2015). Modelling studies have also suggested that sea spray aerosol can be a significant contributor to the INP population in marine environments when the source of other INPs is small (Burrows et al., 2013; Huang et al., 2018; Vergara-Temprado et al., 2017; Wilson et al., 2015). However, our understanding of the flux of INPs from the ocean to the atmosphere is incomplete, and more studies are needed to understand when and where sea spray aerosol is a significant contributor to INP concentrations in the atmosphere.

Mineral dust is transported to the atmosphere by wind erosion, which is sensitive to factors like soil composition, soil moisture, and wind velocity (Ginoux et al., 2001). Mineral dust has been identified as an important contributor to the atmospheric INP population in many field and laboratory studies (Atkinson et al., 2013; Boose et al., 2016; Chen et al., 2018; Conen et al., 2011; Connolly et al., 2009; Creamean et al., 2013; DeMott et al., 2015; Eastwood et al., 2008; Hill et al., 2016; Kaufmann et al., 2016; Klein et al., 2010; Murray et al., 2012; Niedermeier et al., 2010; Niemand et al., 2012; O'Sullivan et al., 2014; Prenni et al., 2009a, b; RangelAlvarado et al., 2015; Steinke et al., 2016; Wex et al., 2014; Wheeler et al., 2015). Modelling studies have also confirmed that mineral dust particles are important atmospheric INPs (Alizadeh-Choobari et al., 2015; Atkinson et al., 2013; Burrows et al., 2013; Hendricks et al., 2011; Hoose et al., 2010; Lohmann and Diehl, 2006; Prenni et al., 2009b; VergaraTemprado et al., 2017).

When glaciers and permafrost in the Arctic melt, erodible soil is exposed. The increased areas of erodible soil can be a potential source of mineral dust in the Arctic (Huang et al., 2015). The ice nucleation properties of dry mineral dust from Qaanaaq (also known as Thule), Greenland, were measured by Fenn and Weickmann (1959) who found that dry mineral dust could nucleate ice at temperatures as warm as $-5^{\circ} \mathrm{C}$. Groot Zwaaftink et al. (2016) also suggested through a modelling study that during the summer local mineral dust sources in the Arctic (mineral dust from latitudes north of $60^{\circ} \mathrm{N}$ ) can dominate the total mineral dust concentrations at the surface. However, previous studies have not yet shown that mineral dust from regional erodible soil could be a major source of INPs in the atmosphere in the Arctic.

In the past 30 years, warming in the Arctic has decreased sea ice and land snow by approximately $20 \%$ and $13 \%$, respectively (Derksen and Brown, 2012). This may have led to an increase in sea spray particles and mineral dust particles from local sources in the region and, as a result, an increase in INPs. Because of the continuing warming trend in this region, the concentration of INPs from these local sources may continue to increase with important implications for the frequency and properties of ice and mixed-phase clouds as well as climate in the region. To evaluate the scale of this feedback mechanism, studies are needed to determine the concentrations and sources of INPs in the Arctic.

To help address the issues raised above, we (1) determined the concentration of INPs in the immersion mode in the Canadian Arctic marine boundary layer during summer 2014, (2) measured the ratio of surface areas of mineral dust particles to sea spray particles, and (3) investigated the source region of the INPs using a particle dispersion model. The specific goals of this study were to quantify the concentrations of INPs in the Canadian Arctic marine boundary layer and to provide insights into the source of INPs in this region during the summer.

\section{Experimental}

\subsection{Sampling locations}

All measurements and sample collections were performed on board the CCGS Amundsen as part of the Network on Climate and Aerosols: Addressing Key Uncertainties in Remote Canadian Environments (NETCARE). The 28 sampling locations are shown in Fig. 1, and the sampling dates, times, and coordinates are detailed in Table S1 in the Supplement. The air temperature, relative humidity, and wind speed during sampling were measured with on-board sensors at approximately $15 \mathrm{~m}$ above sea level and are shown in Fig. S1 in the Supplement. INP concentrations from a subset of the sampling locations (indicated with blue rings around the red symbols in Fig. 1) were previously reported in DeMott et al. (2016) but are also included here as they were collected during the same expedition and with the same methodology. The data reported in DeMott et al. (2016) only included sites in Baffin Bay, days when it did not rain, and conditions when 


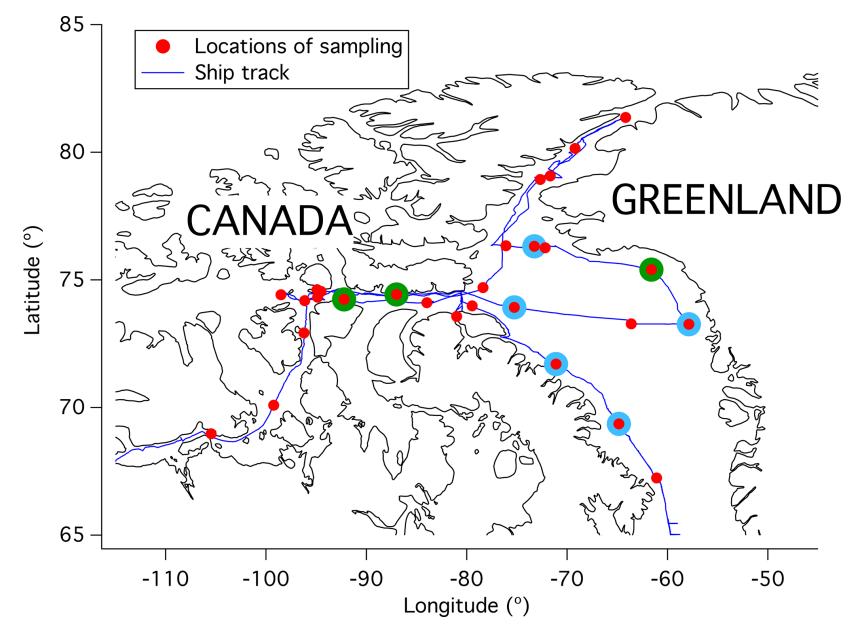

Figure 1. Locations of sampling. Blue circles around the red dots indicate the locations of samples used in DeMott et al. (2016). Green circles around the red dots indicate the locations of samples used for CCSEM-EDX analysis. Information on specific geographical coordinates is given in the Supplement Table S1.

the samples were assumed to have reduced exposure to ship smokestack contamination, i.e. when the apparent wind direction measured on the ship was between 0 and $90^{\circ}$ or between 270 and $360^{\circ}$, where 0 or 360 corresponds to the bow of the ship. (The apparent wind direction is defined as the wind direction experienced by an observer on the moving ship as opposed to the true wind direction, which is defined as the wind direction experienced by an observer when the ship is stationary.)

\subsection{Quantifications of INPs}

To determine the concentration of INPs in the immersion mode, atmospheric particles were collected on hydrophobic glass slides using a micro-orifice single-stage impactor (MOSSI; MSP corp., Shoreview, MN, USA). The freezing properties of the collected particles were then determined with the droplet freezing technique (DFT). The combination (MOSSI-DFT) is similar to the micro-orifice uniform deposit impactor droplet freezing technique (MOUDI-DFT) recently used to determine the size-resolved concentrations of INPs (Mason et al., 2015a, b, 2016). The main difference between the MOSSI-DFT technique and the MOUDI-DFT technique is the use of a single-stage impactor compared to a multistage impactor. The use of a single-stage impactor simplifies the analysis and reduces collection time but sacrifices size information. The MOSSI-DFT technique is also similar to the technique used by others to measure deposition freezing (Knopf et al., 2010, 2014; Wang et al., 2012a, b).

\subsubsection{Micro-orifice single-stage impactor}

The MOSSI was located on the port side of the bridge on the ship, approximately $10 \mathrm{~m}$ in front of the ship's smokestack. During sampling the flow rate through the MOSSI was $10 \mathrm{~L} \mathrm{~min}^{-1}$, resulting in particles with aerodynamic diameters $>0.18 \mu \mathrm{m}$ being collected on the hydrophobic glass slides placed within the MOSSI. The collection time of samples with the MOSSI for INP analysis was approximately 20 min. The MOSSI sampled air through a louvred total suspended particulate (TSP) inlet, which was approximately $15 \mathrm{~m}$ above sea level. The transmission efficiency of $10 \mu \mathrm{m}$ particles through the TSP inlet is $\geq 90 \%$ (Kenny et al., 2005). The nozzle plate within the MOSSI contained 300 micro-orifices. As a result, particles collected on the hydrophobic glass slides beneath the nozzle plate were concentrated into 300 spots. After collection the hydrophobic glass slides containing the particles were stored at $4{ }^{\circ} \mathrm{C}$ for no longer than 3 months prior to analysis.

Particle rebound can be an issue with an inertial impactor such as the MOSSI. Particle rebound occurs when particles impact the collection substrate but are not retained. Rebound has been shown to be reduced at relative humidity $(\mathrm{RH})$ values above $70 \%$, although this depends on the chemical composition of the particles (Bateman et al., 2013; Chen et al., 2011; Fang et al., 1991; Lawson, 1980; Saukko et al., 2012; Vasiliou et al., 1999; Winkler, 1974). During collection with the MOSSI, the RH was always well above $70 \%$ (Fig. S1) with an average of $93 \%$. Furthermore, field measurements of INP concentrations using the MOUDI-DFT (a method similar to the MOSSI-DFT) have shown good agreement with INP concentrations measured with an instrument that is not susceptible to particle rebound (a continuous-flow diffusion chamber) when the RH of the sampled aerosol was as low as $40 \%$ (DeMott et al., 2017; Mason et al., 2016). Nevertheless, particle rebound cannot be ruled out, and therefore the INP concentrations reported here should be considered lower limits.

\subsubsection{Droplet freezing technique}

The droplet freezing technique (Koop et al., 1998; Mason et al., 2015a) was used to determine the concentration of INPs in the immersion mode collected on hydrophobic glass slides using the MOSSI. Briefly, the hydrophobic glass slides containing the collected particles were located in a temperature and RH-controlled flow cell, coupled to an optical microscope with a charge-coupled device (CCD) camera and a $1.25 \times$ objective (Axiolab; Zeiss, Oberkochen, Germany). Typically between 15 and 25 spots of particles (out of the 300 spots generated by the micro-orifices in the nozzle plate) could be monitored in the CCD field of view, which was approximately $12.25 \mathrm{~mm}^{2}$ in area. Water was then condensed on the hydrophobic glass slides by decreasing the temperature to $2{ }^{\circ} \mathrm{C}$ and flowing a gas (pure helium) with a dew point 
of greater than $2{ }^{\circ} \mathrm{C}$ over the hydrophobic glass slides. This resulted in water droplets (with diameters between 100 and $500 \mu \mathrm{m}$ ) condensing on the spots (referred to here as spot droplets) as well as water droplets condensing on other areas of the slides (referred to here as non-spot droplets). After the droplets were condensed, the temperature of the flow cell was decreased at a rate of $10^{\circ} \mathrm{Cmin}^{-1}$. From videos recorded while the temperature was decreasing, the freezing temperature of each droplet was manually determined by observing the change in the droplet's optical properties. The droplets that contained spots of deposited particles were also identified from these videos. For comparison purposes, hydrophobic glass slides that were not exposed to atmospheric particles were also processed in the same way as described above and labelled as "blanks".

The number of INPs as a function of temperature, \#INP( $T$ ), was calculated for each experiment using the following equation:

$\# \operatorname{INP}(T)=\left(-\ln \left(\frac{N_{\mathrm{u}}(T)}{N_{\mathrm{s}}}\right) N_{\mathrm{s}}\right)$,

where $N_{\mathrm{u}}$ is the number of unfrozen droplets covering the spots, and $N_{\mathrm{s}}$ is the number of spots in the field of view. Equation (1) accounts for the possibility that each droplet covering a spot can contain multiple INPs (Vali, 1971).

Equation (1) assumes that each spot was covered by only one droplet. For cases when more than one droplet formed on a spot, the first droplet that froze was considered in Eq. (1). This was expected to give a result equivalent to the case of only one droplet condensing on the spot. For cases when one droplet contained two spots (this occurred for $2 \%$ of the total number of spots in all experiments), an upper limit to the number of INPs was calculated by assuming two droplets covered the two spots and both droplets froze at the observed freezing temperature. A lower limit was calculated by assuming the two spots were covered by two droplets with one droplet freezing at the observed freezing temperature, and the other droplet freezing at $-37^{\circ} \mathrm{C}$ (approximately the homogeneous freezing temperature). If one droplet contained three or more spots, a similar procedure to the above was used to calculate the upper and lower limits to \#INP( $T)$.

The freezing of droplets that did not cover spots was a relatively rare occurrence at the temperature range we focused on in this manuscript $\left(\geq-25^{\circ} \mathrm{C}\right.$; see Sect. 3.1). For example, the ratios of frozen non-spot droplets to frozen spot droplets were 0.02 and 0.07 at -25 and $-20^{\circ} \mathrm{C}$, respectively. We assumed these relatively rare occurrences were due to particles $<0.18 \mu \mathrm{m}$ in diameter that were not focused into spots or due to rebound of a small fraction of the particles off the hydrophobic glass slides. To take into account the INPs not concentrated into the spots, we added the number of frozen nonspot droplets at each temperature to Eq. (1). Since the freezing of non-spot droplets was a relatively rare occurrence, we did not apply the Vali correction (Vali, 1971) to these freezing events.
Approximately $2 \%$ of the freezing events in our experiments occurred by contact freezing between -16.2 and $-34.8^{\circ} \mathrm{C}$. Contact freezing occurred when a frozen droplet grew in size, due to the Wegener-Bergeron-Findeisen process (Findeisen, 1938), and caused the freezing of a neighbouring unfrozen droplet. When calculating concentrations of INPs, contact freezing events were excluded.

The atmospheric concentration of INPs as a function of temperature, $[\operatorname{INP}(T)]$, was calculated with the following equation:

$[\operatorname{INP}(T)]=\# \operatorname{INP}(T) \cdot \frac{300}{N_{\mathrm{s}}} \cdot \frac{1}{V}$,

where $V$ is the volume of air sampled, and $300 / N_{\mathrm{s}}$ is the ratio which takes into account that only a fraction of the total number of spots in the sample was observed in a freezing experiment.

\subsection{Effect of ship emissions on measured INP}

To determine if particles from the ship's smokestack affected the measured INP concentrations, we first investigated the relationship between INP concentrations measured on the ship and the gas-phase HONO concentrations, a product of the reaction between $\mathrm{NO}_{x}$ from the ship's smokestack and water (von Glasow et al., 2003). HONO was measured by a chemical ionization mass spectrometer located on the bridge of the ship about $5 \mathrm{~m}$ in front of the smokestack and approximately $15 \mathrm{~m}$ above sea level. No correlation was observed between HONO and INP concentrations at $-25^{\circ} \mathrm{C}(R=0.05$, $p=0.403)$.

Second, we separated our INP results into samples that were not exposed to smokestack emissions based on measured wind direction and wind speed, and samples that may have been exposed to smokestack emissions based on measured wind direction and wind speed. When the apparent wind direction measured on the ship was between 0 and $90^{\circ}$ or between 270 and $360^{\circ}$ (where 0 or $360^{\circ}$ marks the bow of the ship) and when the apparent wind speed (minute averaged) was higher than $2.5 \mathrm{~m} \mathrm{~s}^{-1}$ for the entire collection time, we assumed that the samples were not exposed to smokestack emissions. Within the uncertainty of the measurements, the INP concentrations measured when samples were not exposed to smokestack emissions (based on the apparent wind direction and speed) are the same as INP concentrations measured when samples may have been exposed to smokestack emissions (Fig. S2). Since the criteria discussed above and the results from the HONO analysis do not suggest measured INP concentrations were influenced by the smokestack emissions, all samples that were collected have been included in this study.

\subsection{Particle dispersion modelling}

FLEXPART-WRF (Brioude et al., 2013), a version of the Lagrangian particle dispersion model FLEXPART (Stohl et 
al., 2005), was used to investigate the potential emission source regions of the INPs. FLEXPART-WRF is driven by meteorology from the Weather Research and Forecasting (WRF) model (Skamarock et al., 2008), and was run in backward mode. The simulation domain for FLEXPART-WRF is shown in Fig. S3.

WRF 3.5.1 was run for the 2014 Amundsen Campaign using initial and boundary conditions from the European Centre for Medium-Range Weather Forecasts (ECMWF) operational analysis (a grid resolution of $0.25^{\circ}$ ). The ECMWF wind, temperature, and RH were used to nudge the WRF run every $6 \mathrm{~h}$ above the atmospheric boundary layer. A full list of the parameterizations and options used for the WRF simulations is given in Table 1 of Wentworth et al. (2016).

FLEXPART-WRF was run in backward mode at $20 \mathrm{~min}$ intervals along the ship track. At the start of a simulation 100000 particles were released from the ship's location in an initial box of volume of $100 \mathrm{~m} \times 100 \mathrm{~m}$ in the horizontal, and from 0 to $60 \mathrm{~m}$ above mean sea level in the vertical. After the particles were released from the initial box, they were followed backward for 7 days with output generated hourly.

As mentioned above, each INP sample was collected over a period of approximately $20 \mathrm{~min}$. As a result, one FLEXPART-WRF run overlapped with each INP sampling period. The FLEXPART-WRF runs that overlapped in time with the INP sampling periods were used to produce potential emission sensitivity (PES) plots for the INP samples. A PES plot was produced by integrating the FLEXPART-WRF output over the 7 days prior to the release of particles. The value of the PES in a particular grid cell is proportional to the particles' residence time in that cell. Since this study is concerned with INP sources from the surface, only particles within the footprint layer (0 to $300 \mathrm{~m}$ altitude) are considered when calculating PES values, and we report PES values for the footprint layer.

\subsection{Statistical analyses}

Pearson correlation analysis was used to compute correlation coefficients $(R) . P$ values were also calculated to determine if the correlations were statistically significant at the $95 \%$ confidence level $(p<0.05)$.

\subsection{Computer controlled scanning electron microscopy with energy dispersive $X$-ray spectroscopy (CCSEM-EDX)}

Immediately following the collection of each sample for INP analysis, additional particle samples were collected to determine the ratio of mineral dust surface area to sea salt surface area by CCSEM-EDX. Particles were collected on transmission electron microscopy (TEM) grids (carbon 200 mesh; Ted Pella) using the same MOSSI used to collect INP samples. Collection time of samples for CCSEM-EDX was approximately $20 \mathrm{~min}$. The samples were kept at room temper- ature for a maximum of 38 months before analysis. Since a long collection time was used $(20 \mathrm{~min})$, particles in the spots directly below the micro-orifices of the nozzle plate in the MOSSI were too close together to identify individual mineral dust and sea salt particles using CCSEM-EDX. To overcome this issue, we only analysed particles on the edge of the spots directly below the micro-orifices of the nozzle plate with CCSEM-EDX. Since the edge was still directly under the nozzle, we assumed that the composition at the edge of the spot was the same as the composition of the whole spot, although we are unable to confirm this assumption.

Due to time constraints, only three samples (two with a high $[\operatorname{INP}(T)]$ and one with a low $[\operatorname{INP}(T)]$ ) were analysed by CCSEM-EDX. The method of using CCSEM-EDX to study atmospheric particles is described by Laskin et al. (2006). Particles with sizes between 0.15 and $5 \mu \mathrm{m}$ (area equivalent diameters) were analysed. First, the atomic percentages of each particle were quantitatively determined from EDX spectra. The EDX data for an individual particle represent an average signal from a raster scan. Then, based on the atomic percentages of each particle, particles were classified as sea salt, mineral dust, or other using the scheme shown in Fig. S4, which is based on the work by Laskin et al. (2012). This classification scheme does not include a mixed mineral dust/sea salt particle category. Rather, any particles that had both sea salt and mineral dust were classified as either mineral dust or sea salt depending on the largest atomic percentage contribution. If we used the classification scheme by Derimian et al. (2017), which explicitly classifies particles as sea salt, mineral dust, and mixed sea salt and mineral dust, no particles would be classified as mixed sea salt and mineral dust particles.

After each particle was classified, the surface areas of mineral dust particles and sea salt particles were determined using 2-D projected images recorded by SEM. Note that the actual surface area of mineral dust is underestimated using this method due to surface irregularities and complex topology. The ratio of mineral dust surface area to sea salt surface area was then determined by dividing the surface area of mineral dust for each sample by the surface area of sea salt for the same sample.

\section{Results and discussion}

\subsection{Measured INP concentrations}

The measured concentrations of INPs in the immersion mode, $[\operatorname{INP}(T)]$, sampled in the Arctic are shown in Fig. 2b and $\mathrm{c}$. The measured $[\operatorname{INP}(T)]$ on new hydrophobic glass slides taken straight from the package, cleaned with ultra pure water, but not exposed to atmospheric particles (referred to as blanks) are shown in red in Fig. 2a and c. Freezing of the blanks occurred over the range of -25.9 to $-38.4{ }^{\circ} \mathrm{C}$. For the droplet sizes and cooling rates used here, homoge- 


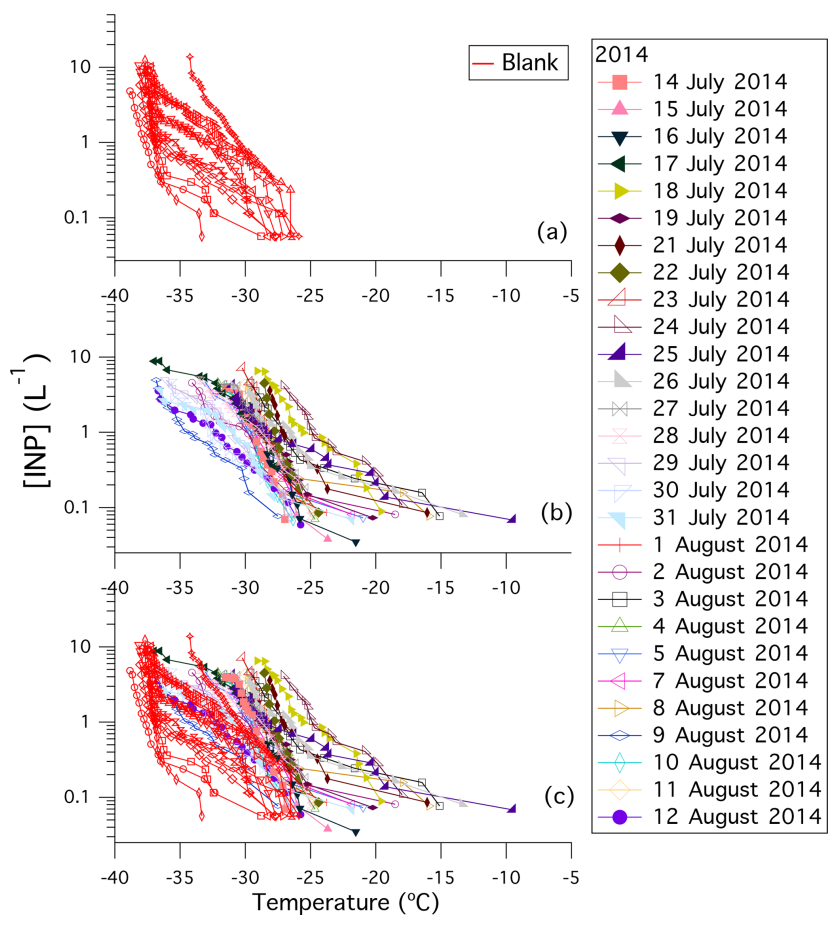

Figure 2. Plot of [INP] $\left(\mathrm{L}^{-1}\right)$ as a function of temperature $\left({ }^{\circ} \mathrm{C}\right)$ for (a) the blanks, (b) the samples, and (c) the blanks and samples. The [INP] $\left(\mathrm{L}^{-1}\right)$ of 11 blanks are shown in (a) and (c). Each blank was performed on a separate hydrophobic glass substrate. Error bars are not shown to improve the visibility of the data in the graph. Error bars in the $x$ direction are $\pm 0.3^{\circ} \mathrm{C}$ for each datapoint. Error bars in the $y$ direction were calculated using nucleation statistics following Koop et al. (1997); the errors for our measured [INP] $\left(\mathrm{L}^{-1}\right)$ can be seen in Fig. S5.

neous freezing occurs at approximately $-37^{\circ} \mathrm{C}$. Therefore, the freezing that occurred in the blanks at temperatures above approximately $-37{ }^{\circ} \mathrm{C}$ was due to heterogeneous freezing likely caused by the hydrophobic glass slides. In the following we will focus on $[\operatorname{INP}(T)]$ at temperatures of $-25^{\circ} \mathrm{C}$ and warmer since no freezing from the blanks was observed in this temperature range. A full time series of $[\operatorname{INP}(T)]$ at $-15,-20$, and $-25^{\circ} \mathrm{C}$ are reported in Fig. S5.

In Fig. 3 we compare recent measurements of $[\operatorname{INP}(T)]$ from several field campaigns in marine environments with the average concentrations measured in the current study. Figure 3 illustrates that the average INP concentrations measured in the current study fall within the range of INP concentrations measured in other marine environments. This observation, however, does not confirm that sea spray aerosol was the major source of INPs during the studies reported here.

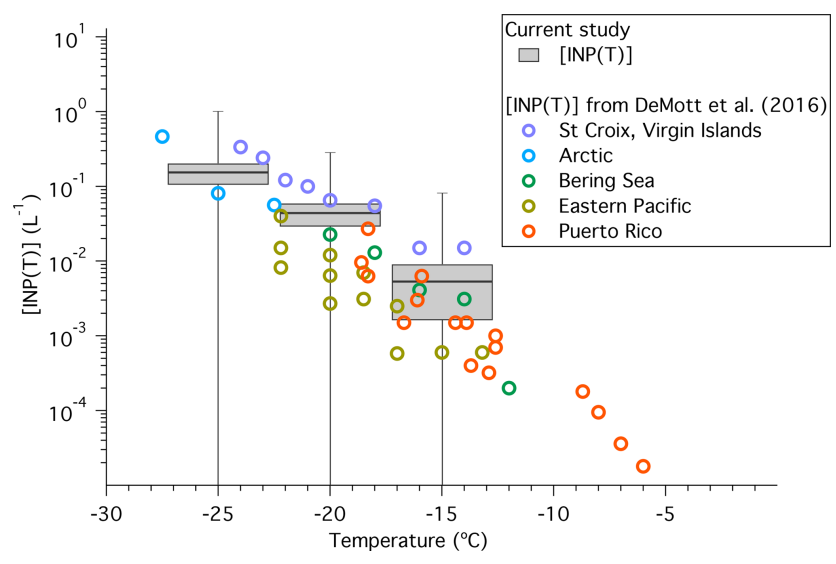

Figure 3. Plot of $[\operatorname{INP}(T)]\left(\mathrm{L}^{-1}\right)$ as a function of temperature including a comparison to discrete field measurements from several recent field studies in marine environments reported in DeMott et al. (2016). The grey boxes represent the average $[\operatorname{INP}(T)]$ reported in this study as well as the standard error of the mean at $-15,-20$, and $-25^{\circ} \mathrm{C}$. The whiskers represent the minima and maxima values of $[\operatorname{INP}(T)]$ measured in the current study. Note the minimum $[\operatorname{INP}(T)]$ measured for all temperatures in the current study was zero. Other coloured circles represent INP measurements from field studies in marine environments reported in DeMott et al. (2016), with the locations indicated in the legend.

\subsection{Measured ratios of mineral dust surface area to sea salt surface area}

For three samples (two with high $[\operatorname{INP}(T)]$ and one with low $[\operatorname{INP}(T)])$, we calculated the ratios of mineral dust surface area to sea salt surface area using CCSEM-EDX. The two samples corresponding to high $[\operatorname{INP}(T)]$ were collected on 21 and 25 July, these days were chosen randomly out of the samples that showed freezing activity at -20 and $-25^{\circ} \mathrm{C}$. The sample corresponding to a low $[\operatorname{INP}(T)]$ was collected on 29 July. This day was chosen randomly out of the samples that did not display any freezing activity above $-25^{\circ} \mathrm{C}$. In Table S2 we report the total number of particles analysed by CCSEM-EDX for each sample, the fraction of particles classified as mineral dust and sea salt particles, and the surface area corresponding to mineral dust and sea salt particles. Shown in Fig. 4a are the calculated ratios of mineral dust surface area to sea salt surface area using surface area measurements from CCSEM-EDX. For the three samples, this ratio ranged from 0.03 to 0.09 . Using this ratio we estimated the ratio of $[\operatorname{INP}(T)]$ from mineral dust, $[\operatorname{INP}(T)]_{\mathrm{MD}}$, to $[\operatorname{INP}(T)]$ from sea spray, $[\operatorname{INP}(T)]_{S s}$, using the following equation:

$\frac{[\mathrm{INP}(T)]_{\mathrm{MD}}}{[\mathrm{INP}(T)]_{\mathrm{SS}}}=\frac{n_{\mathrm{S}}(\mathrm{MD}) \cdot S_{\mathrm{MD}}}{n_{\mathrm{S}}(\mathrm{SS}) \cdot S_{\mathrm{SS}}}$,

where $n_{\mathrm{S}}(\mathrm{SS})$ is the ice active surface site density for sea spray aerosol, $n_{\mathrm{S}}(\mathrm{MD})$ is the ice active surface site density for mineral dust, and $S_{\mathrm{SS}}$ and $S_{\mathrm{MD}}$ are the total surface ar- 


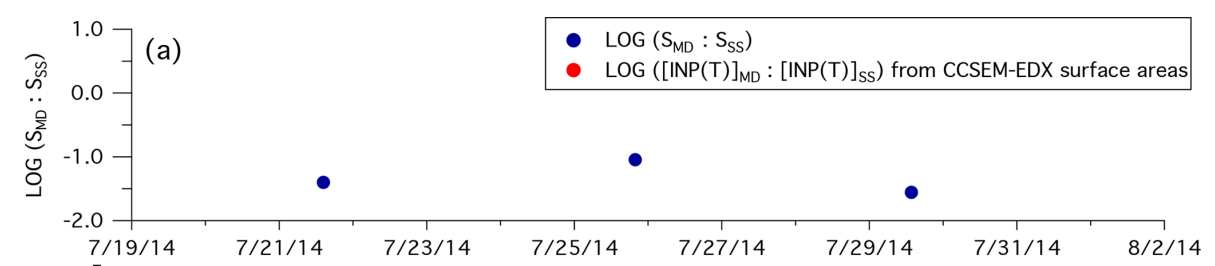

(b) $-25^{\circ} \mathrm{C}$

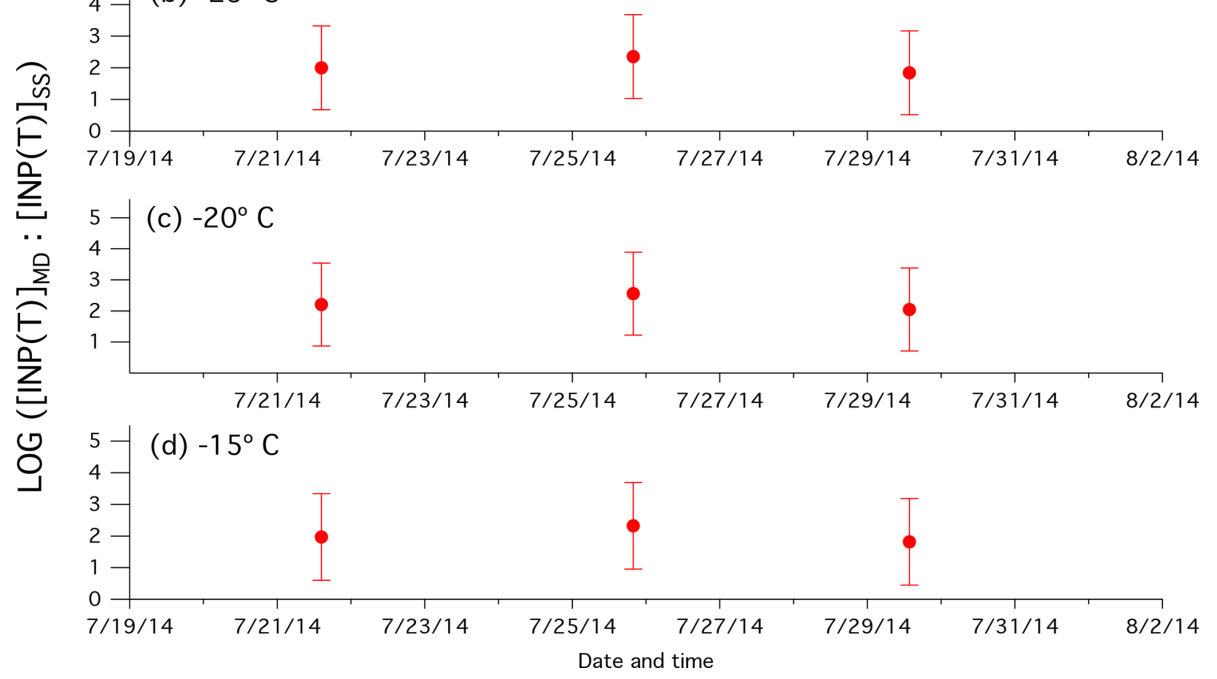

Figure 4. (a) Ratios of the surface area of mineral dust particles to the surface area of sea salt particles measured by CCSEM-EDX (blue circles). Ratios of predicted $[\operatorname{INP}(T)]_{\text {MD }}$ to the predicted $[\operatorname{INP}(T)]_{\text {sS }}$ calculated using CCSEM-EDX measurements (red circles) at $(\mathbf{b})-25^{\circ} \mathrm{C}$, (c) $-20^{\circ} \mathrm{C}$, and $(\mathbf{d})-15^{\circ} \mathrm{C}$.

eas measured by CCSEM-EDX for sea salt and mineral dust, respectively. The $n_{\mathrm{S}}(\mathrm{SS})$ values were determined using laboratory data from DeMott et al. (2016). Recent studies show that $n_{\mathrm{s}}(\mathrm{SS})$ values determined from DeMott et al. (2016) are consistent with values determined in pristine marine environments (McCluskey et al., 2018). The $n_{\mathrm{s}}(\mathrm{MD})$ values were calculated using the exponential function reported by Niemand et al. (2012) that was determined from freezing data of Asian dust, Saharan dust, Canary Islands dust, and Israel dust. For details see Sect. S1 in the Supplement.

The ratios of INP concentrations based on Eq. (3) for freezing temperatures of $-25,-20$, and $-15^{\circ} \mathrm{C}$ are shown in Fig. 4b, c, and d, respectively. These ratios suggest that for the three samples when CCSEM-EDX measurements were performed, the $[\operatorname{INP}(T)]_{\mathrm{MD}}$ are higher than the $[\operatorname{INP}(T)]_{\mathrm{SS}}$ (ratios were between 10 and $10^{3}$, inclusive of errors, at -15 , -20 , and $-25^{\circ} \mathrm{C}$ ), assuming the $n_{\mathrm{s}}$ values used are applicable for the field studies reported here. These results also suggest that mineral dust is a more important contributor to the INP population than sea spray aerosol for the times and locations corresponding to the CCSEM-EDX measurements.

Above we assumed that the ice active surface site density for mineral dust, $n_{\mathrm{s}}(\mathrm{MD})$, in our studies can be calculated with the exponential function reported by Niemand et al. (2012) that was determined from freezing data of Asian dust, Saharan dust, Canary Islands dust, and Israel dust. To test this assumption, we calculated $n_{\mathrm{S}}(\mathrm{MD})$ values using the CCSEM-EDX measurements on 21 and 25 July. Details on how $n_{\mathrm{S}}(\mathrm{MD})$ values were calculated is given in Sect. S2, and the results are shown in Fig. S6. In short, within the uncertainty of the measurements, our calculated $n_{\mathrm{s}}(\mathrm{MD})$ values are consistent with the results from Niemand et al. (2012).

\subsection{Particle dispersion modelling}

Figure 5a shows the averaged PES for the footprint layer for all samples combined and suggests that the source of INPs sampled during the campaign was local (i.e. the Canadian Arctic Archipelago, Baffin Bay, and eastern Greenland).

Figure $5 \mathrm{~b}$ shows the averaged PES for the footprint layer for samples that had the highest INP concentrations (top $36 \%$ of the samples) at $-25^{\circ} \mathrm{C}$. Figure $5 \mathrm{c}$ shows the average PES for the footprint layer for samples that had the lowest INP concentrations (bottom $36 \%$ of the samples) at $-25^{\circ} \mathrm{C}$. A cut-off of $36 \%$ was selected since no freezing was observed in $36 \%$ of the samples at $-25^{\circ} \mathrm{C}$. Figure $5 \mathrm{~d}$ shows the ratio of the average PES for the highest INP concentrations to the average PES for all samples. Figure 5e shows the ratio of the average PES for the lowest INP concentrations to the average PES for all samples. Previous work has shown that ratios of average PES are useful for identifying likely sources (Hirdman et al., 2010). Considering all figures 

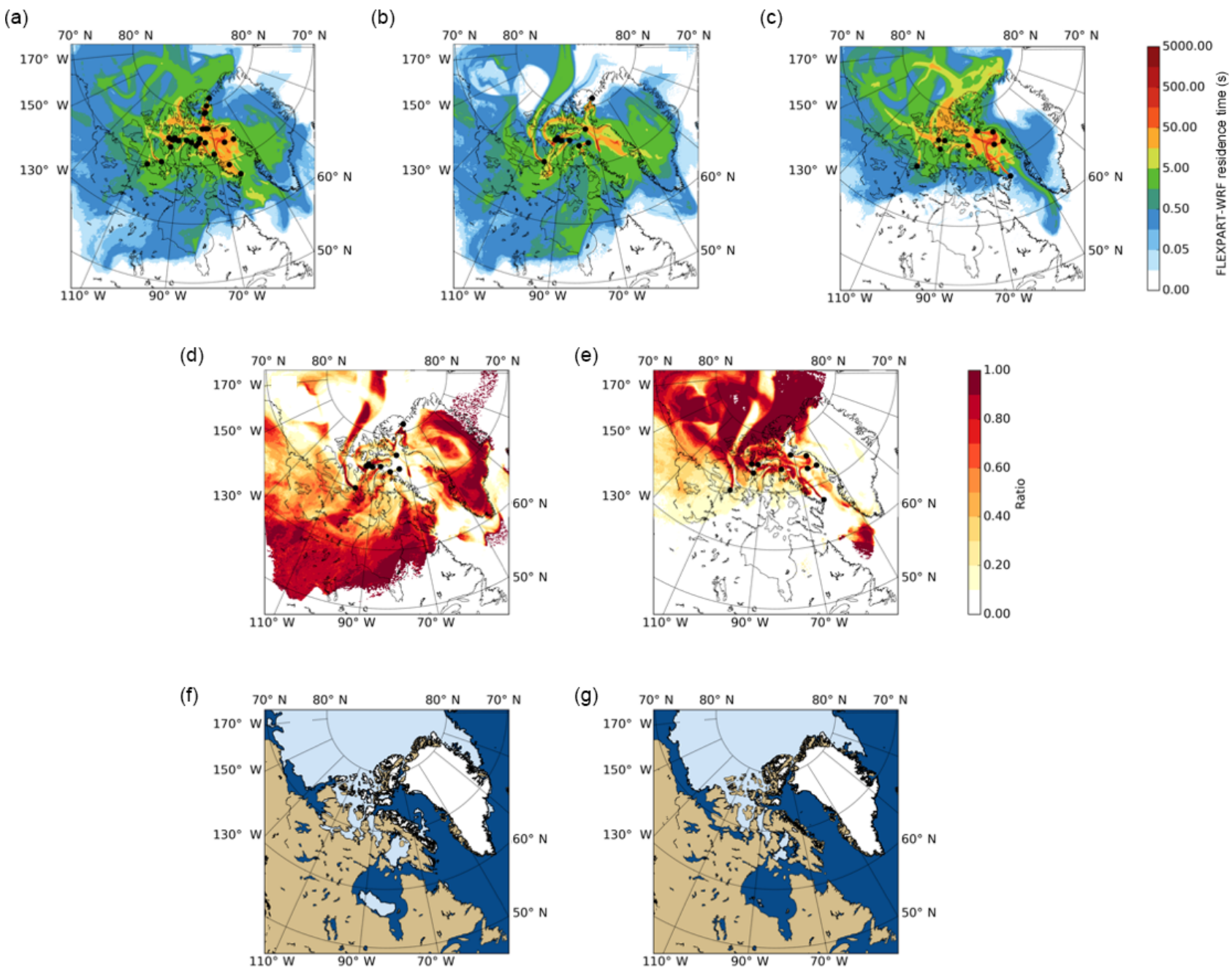

Figure 5. (a-c) Average FLEXPART-WRF footprint potential emission sensitivity (PES) plots for (a) all sampling days, (b) the $36 \%$ of samples with the highest $[\operatorname{INP}(T)]\left(\mathrm{L}^{-1}\right)$, and (c) the $36 \%$ of samples with the lowest $[\operatorname{INP}(T)]\left(\mathrm{L}^{-1}\right)$. Black circles indicate the ship's position at the sampling midtime. (d, e) Maps showing the ratios of panel (b) to panel (a) (shown in panel d) and panel (c) to panel (a) (shown in panel e). (f, g) Maps showing the surface cover type on (f) the first day of sampling (14 July), and (g) the last day of sampling (12 August). Bare land, open water, sea ice, and snow cover are shown as beige, dark blue, light blue, and white, respectively. Note that for this study, lakes are included in the bare land category.

together, the highest INP concentrations are associated with lower-latitude regions such as the Hudson Bay area, eastern Greenland, or north-western continental Canada. On the other hand, the lowest concentrations (below the detection limit at $-25^{\circ} \mathrm{C}$ ) were often associated with regions further north and over Baffin Bay.

Figure $5 f$ and $g$ shows maps of surface cover type (i.e. bare land, open water, sea ice, and snow cover) from the first and last days of the campaign, respectively, based on data from the National Snow and Ice Data Center (NSIDC; National Snow and Ice Data Center, 2008). The maps of surface coverage were combined with the PES values in the footprint layer from FLEXPART to determine the total residence time over each surface type for a given INP sample. Specifically, surface coverage data from the NSIDC were downloaded in
GEOtiff format and converted to vector shape files. The fraction of each FLEXPART grid cell that was over each surface type category (e.g. bare land, open water) was then calculated using these vector shape files. The residence time in a grid cell was then multiplied by the fraction of the cell in each surface type category, and then the results were summed over all grid cells to determine the relative time spent over each surface type.

Correlations between the total residence time over each surface type and the concentration of INPs for each sample at $-15,-20$, and $-25^{\circ} \mathrm{C}$ were then investigated (Table 1 and Fig. S7). This correlation analysis showed statistically significant $(p<0.05)$ positive correlations between the total residence time over bare land in the footprint layer, and both $[\operatorname{INP}(T)]$ values at $-15^{\circ} \mathrm{C}(R=0.5)$ and $-25^{\circ} \mathrm{C}(R=0.4)$. 
Table 1. Correlation coefficients $(R), p$ values, and $n$ values for correlation analysis between $[\operatorname{INP}(T)]\left(\mathrm{L}^{-1}\right)$ at $-15,-20$, and $-25^{\circ} \mathrm{C}$; and the time the air mass spent in the previous 7 days over different surface types within $0-300 \mathrm{~m}$ of the surface. Numbers in bold indicate correlations that are statistically significant $(p<0.05)$.

\begin{tabular}{lrrr|rrr|rrrr}
\hline & \multicolumn{3}{c}{$-15^{\circ} \mathrm{C}$} & & $-20{ }^{\circ} \mathrm{C}$ & & \multicolumn{3}{c}{$-2{ }^{\circ} \mathrm{C}$} \\
\cline { 2 - 9 } & $R$ & $p$ & $n$ & $R$ & $p$ & $n$ & $R$ & $p$ & $n$ \\
\hline Bare land residence time & $\mathbf{0 . 5}$ & $\mathbf{0 . 0 0 8}$ & $\mathbf{2 7}$ & 0.3 & 0.058 & 27 & $\mathbf{0 . 4}$ & $\mathbf{0 . 0 3 3}$ & $\mathbf{2 7}$ \\
Open water residence time & -0.1 & 0.240 & 27 & $-\mathbf{0 . 4}$ & $\mathbf{0 . 0 2 3}$ & $\mathbf{2 7}$ & -0.3 & 0.054 & 27 \\
Sea ice residence time & -0.2 & 0.180 & 27 & $\mathbf{- 0 . 4}$ & $\mathbf{0 . 0 2 8}$ & $\mathbf{2 7}$ & $\mathbf{- 0 . 3}$ & $\mathbf{0 . 0 4 1}$ & $\mathbf{2 7}$ \\
Snow cover residence time & -0.2 & 0.162 & 27 & 0.2 & 0.183 & 27 & 0.0 & 0.449 & 27 \\
\hline
\end{tabular}

On the other hand, a statistically significant negative correlation was observed between the total residence time in the footprint layer over sea ice and both $[\operatorname{INP}(T)]$ values at $-20^{\circ} \mathrm{C}(R=-0.4)$ and $-25^{\circ} \mathrm{C}(R=-0.3)$. Furthermore, a statistically significant negative correlation was observed between the total residence time in the footprint layer over open water and $[\operatorname{INP}(T)]$ at $-20^{\circ} \mathrm{C}(R=-0.4)$. These negative correlations can be explained by a stronger source of INPs from bare land compared to sea ice or open water. Related, Bigg (1996) observed a correlation between INP concentrations measured in the high Arctic and the time since the sampled air mass was last in contact with open ocean $\left(R=-0.54, p<10^{-4}\right)$. In contrast, Bigg and Leck (2001) observed no correlation between INP concentrations and the time since the sampled air mass was last in contact with open ocean.

\section{Conclusions}

Concentrations of INPs in the marine boundary layer were measured at 28 different locations in the Canadian Arctic. Results showed that the concentrations of INPs are similar to concentrations measured in other marine environments.

For three collected samples the ratio of mineral dust surface area to sea spray surface area ranged from 0.03 to 0.09 . Based on these ratios, and the ice active surface site densities of mineral dust and sea spray aerosol determined in previous laboratory studies, mineral dust is a more important contributor to the INP population than sea spray aerosol for the samples analysed (ratios were between 10 and $10^{3}$, inclusive of errors, at $-15,-20$ and $-25^{\circ} \mathrm{C}$ ). This result suggests that INPs from mineral dust are more important contributors to the INP population than sea spray aerosol for the times and locations during sampling.

Particle dispersion modelling suggested that the INPs sampled in this study were likely not from long-range transport. For the days when $[\operatorname{INP}(T)]$ was high, a likely source was the Hudson Bay area, eastern Greenland, or north-western continental Canada. For days when $[\operatorname{INP}(T)]$ was low, the air mass spent more time over regions further north and over Baffin Bay. Correlation analyses showed that there were sta- tistically significant positive correlations between $[\operatorname{INP}(T)]$ at -15 and $-25^{\circ} \mathrm{C}$ and the time the air mass spent over land. Statistically significant negative correlations were observed between $[\operatorname{INP}(T)]$ at -20 and $-25^{\circ} \mathrm{C}$ and the time the air mass spent over sea ice, and $[\operatorname{INP}(T)]$ at $-20^{\circ} \mathrm{C}$ and the time the air mass spent over open water. This correlation analysis together with the particle dispersion modelling provides further evidence that mineral dust is a more important contributor to the INP population than sea spray aerosol, at least when INP concentrations were high. Sea spray aerosol may still have played a role when the INP concentrations were low during sampling.

Previous studies have shown that INPs are ubiquitous in Arctic seawater (Irish et al., 2017; Wilson et al., 2015). Our results show that INPs in the Arctic seawater are not emitted at a high enough rate to compete with mineral dust, at least for the samples with high INP concentrations. The flux of sea spray aerosol to the atmosphere is a function of the wind speed. The minute averaged wind speed during sampling $\left(5.5 \mathrm{~m} \mathrm{~s}^{-1}\right.$ with 10th and 90th percentiles of 2.1 and $10.0 \mathrm{~m} \mathrm{~s}^{-1}$, respectively) was similar to the minute averaged wind speed during the whole campaign $\left(5.2 \mathrm{~m} \mathrm{~s}^{-1}\right.$ with 10th and 90th percentiles of 1.5 and $9.3 \mathrm{~m} \mathrm{~s}^{-1}$, respectively). In addition, our average wind speeds were similar to historical monthly averaged wind speed data from Alert, NU, Canada $\left(3.6 \mathrm{~m} \mathrm{~s}^{-1}\right.$ in July and $3.3 \mathrm{~m} \mathrm{~s}^{-1}$ in August; http://climate.weather.gc.ca; climate ID: 2400300, last access: 19 November 2018). The influence of sea spray aerosol may be more important during periods of higher wind speeds. On the other hand, high wind speeds are also likely to increase the flux of mineral dust from local sources. As warming increases in the Arctic, more erodible soil will be exposed for longer periods of time (Huang et al., 2015). These results, together with our freezing results, suggest that warming in the Arctic will increase concentrations of INPs from mineral dust in the region, with possible implications for cloud properties and climate. Additional studies, including modelling and field studies are needed to quantify the importance of this feedback process for climate in the region. 
Data availability. Underlying material and related items for this manuscript are located in the Supplement.

Supplement. The supplement related to this article is available online at: https://doi.org/10.5194/acp-19-1027-2019-supplement.

Author contributions. AKB, JPDA, and VEI conceptualised the research. VEI, SJH, and SC performed the research. JLT, MDW, JJBW, AC, WRL, JGM, AL, and EG provided additional data. VEI, $\mathrm{SJH}$, and SC analysed the data. VEI, AKB, and SJH wrote the publication. All co-authors reviewed the paper. EG died before submission; we regard his approval for inclusion of his name on this paper as implicit.

Competing interests. The authors declare that they have no conflict of interest.

Special issue statement. This article is part of the special issue "NETCARE (Network on Aerosols and Climate: Addressing Key Uncertainties in Remote Canadian Environments) (ACP/AMT/BG inter-journal SI)". It is not associated with a conference.

Acknowledgements. We would like to thank the scientists, officers, and crew of the CCGS Amundsen for support during the expedition in 2014. We acknowledge the use of data products or imagery from the Land, Atmosphere Near real-time Capability for EOS (LANCE) system operated by the NASA/GSFC/Earth Science Data and Information System (ESDIS) with funding provided by NASA/HQ.

The CCSEM-EDX analysis was performed at the Environmental Molecular Sciences Laboratory at Pacific Northwest National Laboratory (PNNL; Ringgold IDs 47937 and 48781), a US DOE Office of Science user facility sponsored by the Office of Biological and Environmental Research. PNNL is operated for DOE by Battelle Memorial Institute under contract DEAC06-76RL0 1830. We would also like to thank the Natural Sciences and Engineering Research Council of Canada and Fisheries and Oceans Canada for funding.

Edited by: Daniel J. Cziczo

Reviewed by: two anonymous referees

\section{References}

Alizadeh-Choobari, O., Sturman, A., and Zawar-Reza, P.: Global distribution of mineral dust and its impact on radiative fluxes as simulated by WRF-Chem, Meteorol. Atmos. Phys., 127, 635648, https://doi.org/10.1007/s00703-015-0390-4, 2015.

Atkinson, J. D., Murray, B. J., Woodhouse, M. T., Whale, T. F., Baustian, K. J., Carslaw, K. S., Dobbie, S., O'Sullivan, D., Malkin, T. L., and O'Sullivan, D.: The importance of feldspar for ice nucleation by mineral dust in mixed-phase clouds, Nature, 498, 355-358, https://doi.org/10.1038/nature12278, 2013.
Bateman, A. P., Belassein, H., and Martin, S. T.: Impactor Apparatus for the Study of Particle Rebound: Relative Humidity and Capillary Forces, Aerosol Sci. Technol., 6826, 131017104109009, https://doi.org/10.1080/02786826.2013.853866, 2013.

Bigg, E. K.: Ice forming nuclei in the high Arctic, Tellus B, 48, 223-233, https://doi.org/10.1034/j.1600-0889.1996.t01-100007.x, 1996.

Bigg, E. K. and Leck, C.: Cloud-active particles over the central Arctic Ocean, J. Geophys. Res., 106, 32155-32166, 2001.

Blanchard, D. C.: Sea-to-Air Transport of Surface Active Material, Science, 146, 396-397, 1964.

Boose, Y., Welti, A., Atkinson, J., Ramelli, F., Danielczok, A., Bingemer, H. G., Plötze, M., Sierau, B., Kanji, Z. A., and Lohmann, U.: Heterogeneous ice nucleation on dust particles sourced from nine deserts worldwide - Part 1: Immersion freezing, Atmos. Chem. Phys., 16, 15075-15095, https://doi.org/10.5194/acp-16-15075-2016, 2016.

Brioude, J., Arnold, D., Stohl, A., Cassiani, M., Morton, D., Seibert, P., Angevine, W., Evan, S., Dingwell, A., Fast, J. D., Easter, R. C., Pisso, I., Burkhart, J., and Wotawa, G.: The Lagrangian particle dispersion model FLEXPART-WRF version 3.1, Geosci. Model Dev., 6, 1889-1904, https://doi.org/10.5194/gmd-6-18892013, 2013.

Burrows, S. M., Hoose, C., Pöschl, U., and Lawrence, M. G.: Ice nuclei in marine air: biogenic particles or dust?, Atmos. Chem. Phys., 13, 245-267, https://doi.org/10.5194/acp-13-2452013, 2013.

Chen, J., Wu, Z., Augustin-Bauditz, S., Grawe, S., Hartmann, M., Pei, X., Liu, Z., Ji, D., and Wex, H.: Icenucleating particle concentrations unaffected by urban air pollution in Beijing, China, Atmos. Chem. Phys., 18, 3523-3539, https://doi.org/10.5194/acp-18-3523-2018, 2018.

Chen, S.-C., Tsai, C.-J., Chen, H.-D., Huang, C.-Y., and Roam, G.-D.: The Influence of Relative Humidity on Nanoparticle Concentration and Particle Mass Distribution Measurements by the MOUDI, Aerosol Sci. Technol., 45, 596-603, https://doi.org/10.1080/02786826.2010.551557, 2011.

Coluzza, I., Creamean, J., Rossi, M. J., Wex, H., Alpert, P. A., Bianco, V., Boose, Y., Dellago, C., Felgitsch, L., FröhlichNowoisky, J., Herrmann, H., Jungblut, S., Kanji, Z. A., Menzl, G., Moffett, B., Moritz, C., Mutzel, A., Pöschl, U., Schauperl, M., Scheel, J., Stopelli, E., Stratmann, F., Grothe, H., and Schmale, D. G.: Perspectives on the future of ice nucleation research: Research needs and Unanswered questions identified from two international workshops, Atmosphere, 8, 1-28, https://doi.org/10.3390/atmos8080138, 2017.

Conen, F., Morris, C. E., Leifeld, J., Yakutin, M. V., and Alewell, C.: Biological residues define the ice nucleation properties of soil dust, Atmos. Chem. Phys., 11, 9643-9648, https://doi.org/10.5194/acp-11-9643-2011, 2011.

Connolly, P. J., Möhler, O., Field, P. R., Saathoff, H., Burgess, R., Choularton, T., and Gallagher, M.: Studies of heterogeneous freezing by three different desert dust samples, Atmos. Chem. Phys., 9, 2805-2824, https://doi.org/10.5194/acp-9-2805-2009, 2009.

Creamean, J. M., Suski, K. J., Rosenfeld, D., Cazorla, A., DeMott, P. J., Sullivan, R. C., White, A. B., Ralph, F. M., Minnis, P., Comstock, J. M., Tomlinson, J. M., and Prather, K. A.: 
Dust and biological aerosols from the Sahara and Asia influence precipitation in the western U.S., Science, 339, 1572-1578, https://doi.org/10.1126/science.1227279, 2013.

Creamean, J. M., Kirpes, R. M., Pratt, K. A., Spada, N. J., Maahn, M., de Boer, G., Schnell, R. C., and China, S.: Marine and terrestrial influences on ice nucleating particles during continuous springtime measurements in an Arctic oilfield location, Atmos. Chem. Phys., 18, 18023-18042, https://doi.org/10.5194/acp-1818023-2018, 2018.

DeMott, P. J., Prenni, A. J., McMeeking, G. R., Sullivan, R. C., Petters, M. D., Tobo, Y., Niemand, M., Möhler, O., Snider, J. R., Wang, Z., and Kreidenweis, S. M.: Integrating laboratory and field data to quantify the immersion freezing ice nucleation activity of mineral dust particles, Atmos. Chem. Phys., 15, 393-409, https://doi.org/10.5194/acp-15-393-2015, 2015.

DeMott, P. J., Hill, T. C. J., McCluskey, C. S., Prather, K. A., Collins, D. B., Sullivan, R. C., Ruppel, M. J., Mason, R. H., Irish, V. E., Lee, T., Hwang, C. Y., Rhee, T. S., Snider, J. R., McMeeking, G. R., Dhaniyala, S., Lewis, E. R., Wentzell, J. J. B., Abbatt, J., Lee, C., Sultana, C. M., Ault, A. P., Axson, J. L., Diaz Martinez, M., Venero, I., Santos-Figueroa, G., Stokes, M. D., Deane, G. B., Mayol-Bracero, O. L., Grassian, V. H., Bertram, T. H., Bertram, A. K., Moffett, B. F., and Franc, G. D.: Sea spray aerosol as a unique source of ice nucleating particles, P. Natl. Acad. Sci. USA, 113, 5797-5803, https://doi.org/10.1073/pnas.1514034112, 2016.

DeMott, P. J., Hill, T. C. J., Petters, M. D., Bertram, A. K., Tobo, Y., Mason, R. H., Suski, K. J., McCluskey, C. S., Levin, E. J. T., Schill, G. P., Boose, Y., Rauker, A. M., Miller, A. J., Zaragoza, J., Rocci, K., Rothfuss, N. E., Taylor, H. P., Hader, J. D., Chou, C., Huffman, J. A., Pöschl, U., Prenni, A. J., and Kreidenweis, S. M.: Comparative measurements of ambient atmospheric concentrations of ice nucleating particles using multiple immersion freezing methods and a continuous flow diffusion chamber, Atmos. Chem. Phys., 17, 11227-11245, https://doi.org/10.5194/acp-1711227-2017, 2017

Derimian, Y., Choël, M., Rudich, Y., Deboudt, K., Dubovik, O., Laskin, A., Legrand, M., Damiri, B., Koren, I., Unga, F., Moreau, M., Andreae, M. O., and Karnieli, A.: Effect of sea breeze circulation on aerosol mixing state and radiative properties in a desert setting, Atmos. Chem. Phys., 17, 11331-11353, https://doi.org/10.5194/acp-17-11331-2017, 2017.

Derksen, C. and Brown, R.: Spring snow cover extent reductions in the 2008-2012 period exceeding climate model projections, Geophys. Res. Lett., 39, 1-6, https://doi.org/10.1029/2012GL053387, 2012.

Després, V. R., Huffman, A. J., Burrows, S. M., Hoose, C., Safatov, A. S., Buryak, G., Fröhlich-Nowoisky, J., Elbert, W., Andreae, M. O., Pöschl, U., and Jaenicke, R.: Primary biological aerosol particles in the atmosphere: a review, Tellus B, 64, 15598-15656, https://doi.org/10.3402/tellusb.v64i0.15598, 2012.

Eastwood, M. L., Cremel, S., Gehrke, C., Girard, E., and Bertram, A. K.: Ice nucleation on mineral dust particles: Onset conditions, nucleation rates and contact angles, J. Geophys. Res.-Atmos., 113, 1-9, https://doi.org/10.1029/2008JD010639, 2008.

Fang, C. P., McMurry, P. H., Marple, V. A., and Rubow, K. L.: Effect of flow-induced relative humidity changes on size cuts for sulfuric acid droplets in the Microorifice Uniform De- posit Impactor (MOUDI), Aerosol Sci. Tech., 14, 266-277, https://doi.org/10.1080/02786829108959489, 1991.

Fenn, R. W. and Weickmann, H. K.: Some results of aerosol measurements, Geofis. pura e Appl., 42, 53-61, 1959.

Findeisen, W.: Colloidal meteorological processes in the formation of precipitation, Meteorol. Zeitschrift, 55, 121-133, https://doi.org/10.1127/metz/2015/0675, 1938.

Ginoux, P., Chin, M., Tegen, I., Prospero, J. M., Holben, B., Dubovik, O., and Lin, S.-J.: Sources and distributions of dust aerosols simulated with the GOCART model, J. Geophys. Res., 106, 20255-20273, 2001.

Groot Zwaaftink, C. D., Grythe, H., Skov, H., and Stohl, A.: Substantial contribution of northern high-latitude sources to mineral dust in the Arctic, J. Geophys. Res.-Atmos., 121, 13678-13697, https://doi.org/10.1002/2016JD025482, 2016.

Harrington, J. Y., Reisin, T., Cotton, W. R., and Kreidenweis, S. M.: Cloud resolving simulations of Arctic stratus part II: Transition-season clouds, Atmos. Res., 51, 45-75, https://doi.org/10.1016/S0169-8095(98)00098-2, 1999.

Hendricks, J., Kärcher, B., and Lohmann, U.: Effects of ice nuclei on cirrus clouds in a global climate model, J. Geophys. Res.-Atmos., 116, 1-24, https://doi.org/10.1029/2010JD015302, 2011.

Hill, T. C. J., DeMott, P. J., Tobo, Y., Fröhlich-Nowoisky, J., Moffett, B. F., Franc, G. D., and Kreidenweis, S. M.: Sources of organic ice nucleating particles in soils, Atmos. Chem. Phys., 16, 7195-7211, https://doi.org/10.5194/acp-16-7195-2016, 2016.

Hirdman, D., Burkhart, J. F., Sodemann, H., Eckhardt, S., Jefferson, A., Quinn, P. K., Sharma, S., Ström, J., and Stohl, A.: Long-term trends of black carbon and sulphate aerosol in the Arctic: changes in atmospheric transport and source region emissions, Atmos. Chem. Phys., 10, 9351-9368, https://doi.org/10.5194/acp-109351-2010, 2010.

Hoose, C. and Möhler, O.: Heterogeneous ice nucleation on atmospheric aerosols: a review of results from laboratory experiments, Atmos. Chem. Phys., 12, 9817-9854, https://doi.org/10.5194/acp-12-9817-2012, 2012.

Hoose, C., Kristjánsson, J. E., Chen, J.-P., and Hazra, A.: A Classical-Theory-Based Parameterization of Heterogeneous Ice Nucleation by Mineral Dust, Soot, and Biological Particles in a Global Climate Model, J. Atmos. Sci., 67, 2483-2503, https://doi.org/10.1175/2010JAS3425.1, 2010.

Huang, J., Yu, H., Guan, X., Wang, G., and Guo, R.: Accelerated dryland expansion under climate change, Nat. Clim. Change, 6, 166-171, https://doi.org/10.1038/nclimate2837, 2015.

Huang, W. T. K., Ickes, L., Tegen, I., Rinaldi, M., Ceburnis, D., and Lohmann, U.: Global relevance of marine organic aerosol as ice nucleating particles, Atmos. Chem. Phys., 18, 11423-11445, https://doi.org/10.5194/acp-18-11423-2018, 2018.

Irish, V. E., Elizondo, P., Chen, J., Chou, C., Charette, J., Lizotte, M., Ladino, L. A., Wilson, T. W., Gosselin, M., Murray, B. J., Polishchuk, E., Abbatt, J. P. D., Miller, L. A., and Bertram, A. K.: Ice-nucleating particles in Canadian Arctic sea-surface microlayer and bulk seawater, Atmos. Chem. Phys., 17, 10583-10595, https://doi.org/10.5194/acp-17-10583-2017, 2017.

Kanji, Z. A., Ladino, L. A., Wex, H., Boose, Y., BurkertKohn, M., Cziczo, D. J., and Krämer, M.: Chapter 1: Overview of Ice Nucleating Particles, Meteorol. Monogr., 
58, 1.1-1.33, https://doi.org/10.1175/AMSMONOGRAPHS-D16-0006.1, 2017.

Kaufmann, L., Marcolli, C., Hofer, J., Pinti, V., Hoyle, C. R., and Peter, T.: Ice nucleation efficiency of natural dust samples in the immersion mode, Atmos. Chem. Phys., 16, 11177-11206, https://doi.org/10.5194/acp-16-11177-2016, 2016.

Kenny, L., Beaumont, G., Gudmundsson, A., Thorpe, A., and Koch, W.: Aspiration and sampling efficiencies of the TSP and louvered particulate matter inlets, J. Environ. Monit., 7, 481-487, https://doi.org/10.1039/b419001g, 2005.

Klein, H., Nickovic, S., Haunold, W., Bundke, U., Nillius, B., Ebert, M., Weinbruch, S., Schuetz, L., Levin, Z., Barrie, L. A., and Bingemer, H.: Saharan dust and ice nuclei over Central Europe, Atmos. Chem. Phys., 10, 10211-10221, https://doi.org/10.5194/acp-10-10211-2010, 2010.

Knopf, D. A., Wang, B., Laskin, A., Moffet, R. C., and Gilles, M. K.: Heterogeneous nucleation of ice on anthropogenic organic particles collected in Mexico City, Geophys. Res. Lett., 37, L11803-L11808, https://doi.org/10.1029/2010GL043362, 2010.

Knopf, D. A., Alpert, P. A., Wang, B., Brien, R. E. O., Kelly, S. T., Laskin, A., Gilles, M. K., and Moffet, R. C.: Microspectroscopic imaging and characterization of individually identified ice nucleating particles from a case field study, J. Geophys. Res.-Atmos., 119, 365-381, https://doi.org/10.1002/2014JD021866, 2014.

Koop, T., Luo, B., Biermann, U. M., Crutzen, P. J., and Peter, T.: Freezing of $\mathrm{HNO}_{3} / \mathrm{H}_{2} \mathrm{SO}_{4} / \mathrm{H}_{2} \mathrm{O}$ Solutions at Stratospheric Temperatures: Nucleation Statistics and Experiments, J. Phys. Chem. A, 101, 1117-1133, https://doi.org/10.1021/jp9626531, 1997.

Koop, T., Ng, H. P., Molina, L. T., and Molina, M. J.: A New Optical Technique to Study Aerosol Phase Transitions: The Nucleation of Ice from $\mathrm{H}_{2} \mathrm{SO}_{4}$ Aerosols, J. Phys. Chem. A, 102, 8924-8931, https://doi.org/10.1021/jp9828078, 1998.

Korolev, A., McFarquhar, G., Field, P. R., Franklin, C., Lawson, P., Wang, Z., Williams, E., Abel, S. J., Axisa, D., Borrmann, S., Crosier, J., Fugal, J., Krämer, M., Lohmann, U., Schlenczek, O., and Wendisch, M.: Mixedphase clouds: progress and challenges, Meteorol. Monogr., 58, 5.1-5.50, https://doi.org/10.1175/AMSMONOGRAPHS-D17-0001.1, 2017.

Laskin, A., Cowin, J. P., and Iedema, M. J.: Analysis of individual environmental particles using modern methods of electron microscopy and X-ray microanalysis, J. Electron Spectrosc., 150, 260-274, https://doi.org/10.1016/j.elspec.2005.06.008, 2006.

Laskin, A., Moffet, R. C., Gilles, M. K., Fast, J. D., Zaveri, R. A., Wang, B., Nigge, P., and Shutthanandan, J.: Tropospheric chemistry of internally mixed sea salt and organic particles: Surprising reactivity of $\mathrm{NaCl}$ with weak organic acids, J. Geophys. Res.-Atmos., 117, 1-12, https://doi.org/10.1029/2012JD017743, 2012.

Lawson, D. R.: Impaction surface coatings intercomparison and measurements with cascade impactors, Atmos. Environ., 14, 195-199, https://doi.org/10.1016/0004-6981(80)90278-4, 1980.

Lohmann, U. and Diehl, K.: Sensitivity Studies of the Importance of Dust Ice Nuclei for the Indirect Aerosol Effect on Stratiform Mixed-Phase Clouds, J. Atmos. Sci., 63, 968-982, https://doi.org/10.1175/JAS3662.1, 2006.

Mason, R. H., Chou, C., McCluskey, C. S., Levin, E. J. T., Schiller, C. L., Hill, T. C. J., Huffman, J. A., DeMott, P. J., and Bertram, A. K.: The micro-orifice uniform deposit impactor- droplet freezing technique (MOUDI-DFT) for measuring concentrations of ice nucleating particles as a function of size: improvements and initial validation, Atmos. Meas. Tech., 8, 24492462, https://doi.org/10.5194/amt-8-2449-2015, 2015 a.

Mason, R. H., Si, M., Li, J., Chou, C., Dickie, R., Toom-Sauntry, D., Pöhlker, C., Yakobi-Hancock, J. D., Ladino, L. A., Jones, K., Leaitch, W. R., Schiller, C. L., Abbatt, J. P. D., Huffman, J. A., and Bertram, A. K.: Ice nucleating particles at a coastal marine boundary layer site: correlations with aerosol type and meteorological conditions, Atmos. Chem. Phys., 15, 12547-12566, https://doi.org/10.5194/acp-15-12547-2015, 2015b.

Mason, R. H., Si, M., Chou, C., Irish, V. E., Dickie, R., Elizondo, P., Wong, R., Brintnell, M., Elsasser, M., Lassar, W. M., Pierce, K. M., Leaitch, W. R., MacDonald, A. M., Platt, A., ToomSauntry, D., Sarda-Estève, R., Schiller, C. L., Suski, K. J., Hill, T. C. J., Abbatt, J. P. D., Huffman, J. A., DeMott, P. J., and Bertram, A. K.: Size-resolved measurements of ice-nucleating particles at six locations in North America and one in Europe, Atmos. Chem. Phys., 16, 1637-1651, https://doi.org/10.5194/acp16-1637-2016, 2016.

McCluskey, C. S., Ovadnevaite, J., Rinaldi, M., Atkinson, J., Belosi, F., Ceburnis, D., Marullo, S., Hill, T. C. J., Lohmann, U., Kanji, Z. A., O'Dowd, C., Kreidenweis, S. M., and DeMott, P. J.: Marine and Terrestrial Organic Ice-Nucleating Particles in Pristine Marine to Continentally Influenced Northeast Atlantic Air Masses, J. Geophys. Res.-Atmos., 123, 6196-6212, https://doi.org/10.1029/2017JD028033, 2018.

Murray, B. J., O'Sullivan, D., Atkinson, J. D., and Webb, M. E.: Ice nucleation by particles immersed in supercooled cloud droplets, Chem. Soc. Rev., 41, 6519-6554, https://doi.org/10.1039/c2cs35200a, 2012.

National Snow and Ice Data Center: IMS daily Northern Hemisphere snow and ice analysis at $1 \mathrm{~km}, 4 \mathrm{~km}$, and $24 \mathrm{~km}$ resolutions, Colorado, USA, 2008.

Niedermeier, D., Hartmann, S., Shaw, R. A., Covert, D., Mentel, T. F., Schneider, J., Poulain, L., Reitz, P., Spindler, C., Clauss, T., Kiselev, A., Hallbauer, E., Wex, H., Mildenberger, K., and Stratmann, F.: Heterogeneous freezing of droplets with immersed mineral dust particles - measurements and parameterization, Atmos. Chem. Phys., 10, 3601-3614, https://doi.org/10.5194/acp10-3601-2010, 2010.

Niemand, M., Möhler, O., Vogel, B., Vogel, H., Hoose, C., Connolly, P., Klein, H., Bingemer, H., DeMott, P., Skrotzki, J., and Leisner, T.: A Particle-Surface-Area-Based Parameterization of Immersion Freezing on Desert Dust Particles, J. Atmos. Sci., 69, 3077-3092, https://doi.org/10.1175/JAS-D-11-0249.1, 2012.

O'Sullivan, D., Murray, B. J., Malkin, T. L., Whale, T. F., Umo, N. S., Atkinson, J. D., Price, H. C., Baustian, K. J., Browse, J., and Webb, M. E.: Ice nucleation by fertile soil dusts: relative importance of mineral and biogenic components, Atmos. Chem. Phys., 14, 1853-1867, https://doi.org/10.5194/acp-141853-2014, 2014.

Prenni, A. J., DeMott, P. J., Rogers, D. C., Kreidenweis, S. M., Mcfarquhar, G. M., Zhang, G., and Poellot, M. R.: Ice nuclei characteristics from M-PACE and their relation to ice formation in clouds, Tellus B, 61B, 436-448, https://doi.org/10.1111/j.16000889.2009.00415.x, 2009a.

Prenni, A. J., Petters, M. D., Kreidenweis, S. M., Heald, C. L., Martin, S. T., Artaxo, P., Garland, R. M., Wollny, A. G., and 
Pöschl, U.: Relative roles of biogenic emissions and Saharan dust as ice nuclei in the Amazon basin, Nat. Geosci., 2, 402-405, https://doi.org/10.1038/ngeo517, 2009 b.

Rangel-Alvarado, R. B., Nazarenko, Y., and Ariya, P. A.: Snowborne nanosized particles: Abundance, distribution, composition, and significance in ice nucleation processes, J. Geophys. Res.Atmos., 120, 760-774, https://doi.org/10.1002/2015JD023773, 2015.

Rosinski, J., Haagenson, P. L., Nagamoto, C. T., and Parungo, F.: Ice-forming nuclei of maritime origin, J. Aerosol Sci., 17, 2346, https://doi.org/10.1016/0021-8502(86)90004-2, 1986.

Saukko, E., Kuuluvainen, H., and Virtanen, A.: A method to resolve the phase state of aerosol particles, Atmos. Meas. Tech., 5, 259265, https://doi.org/10.5194/amt-5-259-2012, 2012.

Schnell, R. C.: Ice Nuclei in Seawater, Fog Water and Marine Air off the Coast of Nova Scotia: Summer 1975, J. Atmos. Sci., 34, 1299-1305, 1977.

Schnell, R. C. and Vali, G.: Freezing nuclei in marine waters, Tellus, 27, 321-323, https://doi.org/10.3402/tellusa.v27i3.9911, 1975.

Schnell, R. C. and Vali, G.: Biogenic Ice Nuclei: Part I. Terrestrial and Marine Sources, J. Atmos. Sci., 33, 1554-1564, https://doi.org/10.1175/15200469(1976)033<1554:BINPIT>2.0.CO;2, 1976.

Skamarock, W. C., Klemp, J. B., Dudhia, J., Gill, D. O., Barker, D. M., Duda, M. G., Huang, X. Y., Wang, W., and Powers, J. G.: A description of the advanced research WRF version 3, Tech. Note, NCAR/TN 475+STR, 125 pp., Natl. Cent. for Atmos. Res., Boulder, CO, USA, 2008.

Steinke, I., Funk, R., Busse, J., Iturri, A., Kirchen, S., Leue, M., Möhler, O., Schwartz, T., Schnaiter, M., Sierau, B., Toprak, E., Ullrich, R., Ulrich, A., Hoose, C., and Leisner, T.: Ice nucleation activity of agricultural soil dust aerosols from Mongolia, Argentina and Germany, J. Geophys. Res.-Atmos., 121, 1355913576, https://doi.org/10.1002/2016JD025160, 2016.

Stohl, A., Forster, C., Frank, A., Seibert, P., and Wotawa, G.: Technical note: The Lagrangian particle dispersion model FLEXPART version 6.2, Atmos. Chem. Phys., 5, 2461-2474, https://doi.org/10.5194/acp-5-2461-2005, 2005.

Szyrmer, W. and Zawadzki, I.: Biogenic and Anthropogenic Sources of Ice-Forming Nuclei: A Review, B. Am. Meteorol. Soc., 78, 209-228, 1997.

Vali, G.: Quantitative Evaluation of Experimental Results on the Heterogeneous Freezing Nucleation of Supercooled Liquids, J. Atmos. Sci., 28, 402-409, 1971.

Vasiliou, J. G., Sorensen, D., and McMurry, P. H.: Sampling at controlled relative humidity with a cascade impactor, Atmos. Environ., 33, 1049-1056, https://doi.org/10.1016/S13522310(98)00323-9, 1999.

Vergara-Temprado, J., Murray, B. J., Wilson, T. W., O’Sullivan, D., Browse, J., Pringle, K. J., Ardon-Dryer, K., Bertram, A. K., Burrows, S. M., Ceburnis, D., DeMott, P. J., Mason, R. H., O'Dowd, C. D., Rinaldi, M., and Carslaw, K. S.: Contribution of feldspar and marine organic aerosols to global ice nucleating particle concentrations, Atmos. Chem. Phys., 17, 3637-3658, https://doi.org/10.5194/acp-17-3637-2017, 2017. von Glasow, R., Lawrence, M. G., Sander, R., and Crutzen, P. J.: Modeling the chemical effects of ship exhaust in the cloudfree marine boundary layer, Atmos. Chem. Phys., 3, 233-250, https://doi.org/10.5194/acp-3-233-2003, 2003.

Wang, B., Lambe, A. T., Massoli, P., Onasch, T. B., Davidovits, P., Worsnop, D. R., and Knopf, D. A.: The deposition ice nucleation and immersion freezing potential of amorphous secondary organic aerosol: Pathways for ice and mixed-phase cloud formation, J. Geophys. Res.-Atmos., 117, D16209-D16231, https://doi.org/10.1029/2012JD018063, 2012a.

Wang, B., Laskin, A., Roedel, T., Gilles, M. K., Moffet, R. C., Tivanski, A. V., and Knopf, D. A.: Heterogeneous ice nucleation and water uptake by field-collected atmospheric particles below 273 K, J. Geophys. Res.-Atmos., 117, D00V19-D00V34, https://doi.org/10.1029/2012JD017446, 2012b.

Wang, X., Deane, G. B., Moore, K. A., Ryder, O. S., Stokes, M. D., Beall, C. M., Collins, D. B., Santander, M. V, Burrows, S. M., Sultana, C. M., and Prather, K. A.: The role of jet and film drops in controlling the mixing state of submicron sea spray aerosol particles, P. Natl. Acad. Sci. USA, 114, 6978-6983, https://doi.org/10.1073/pnas.1702420114, 2017.

Wentworth, G. R., Murphy, J. G., Croft, B., Martin, R. V., Pierce, J. R., Côté, J.-S., Courchesne, I., Tremblay, J.-É., Gagnon, J., Thomas, J. L., Sharma, S., Toom-Sauntry, D., Chivulescu, A., Levasseur, M., and Abbatt, J. P. D.: Ammonia in the summertime Arctic marine boundary layer: sources, sinks, and implications, Atmos. Chem. Phys., 16, 1937-1953, https://doi.org/10.5194/acp-16-1937-2016, 2016.

Wex, H., DeMott, P. J., Tobo, Y., Hartmann, S., Rösch, M., Clauss, T., Tomsche, L., Niedermeier, D., and Stratmann, F.: Kaolinite particles as ice nuclei: learning from the use of different kaolinite samples and different coatings, Atmos. Chem. Phys., 14, 55295546, https://doi.org/10.5194/acp-14-5529-2014, 2014.

Wheeler, M. J., Mason, R. H., Steunenberg, K., Wagstaff, M., Chou, C., and Bertram, A. K.: Immersion freezing of supermicron mineral dust particles: Freezing results, testing different schemes for describing ice nucleation, and ice nucleation active site densities, J. Phys. Chem. A, 119, 4358-4372, https://doi.org/10.1021/jp507875q, 2015.

Wilson, T. W., Ladino, L. A., Alpert, P. A., Breckels, M. N., Brooks, I. M., Browse, J., Burrows, S. M., Carslaw, K. S., Huffman, J. A., Judd, C., Kilthau, W. P., Mason, R. H., McFiggans, G., Miller, L. A., Nájera, J. J., Polishchuk, E., Rae, S., Schiller, C. L., Si, M., Temprado, J. V., Whale, T. F., Wong, J. P. S., Wurl, O., Yakobi-Hancock, J. D., Abbatt, J. P. D., Aller, J. Y., Bertram, A. K., Knopf, D. A., and Murray, B. J.: A marine biogenic source of atmospheric ice-nucleating particles, Nature, 525, 234-238, https://doi.org/10.1038/nature14986, 2015.

Winkler, P.: Relative humidity and the adhesion of atmospheric particles to the plates of impactors, J. Aerosol Sci., 5, 235-240, https://doi.org/10.1016/0021-8502(74)90058-5, 1974. 